A N N A LES

UNIVERSITATIS MARIAE CURIE-SKŁODOWSKA

LUBLIN - POLONIA

VOL. LXVI, 1

SECTIO G

2019

Uniwersytet Marii Curie-Skłodowskiej w Lublinie

ANDRZEJ WRZYSZCZ

andrzej.wrzyszcz@poczta.umcs.lublin.pl

ORCID: 0000-0002-9824-4251

\title{
Ustrój i prawo w Generalnym Gubernatorstwie w poglądach prawników niemieckich na łamach czasopisma „Deutsches Recht” w czasie II wojny światowej
}

System and Law in the General Government in the Views of German Lawyers in the "Deutsches Recht" Magazine during World War II

Czasopismo „Deutsches Recht” było w interesującym nas okresie II wojny światowej ważnym periodykiem prawniczym, na łamach którego prezentowano poglądy jurystów identyfikujących się z ideologią nazistowską. Znajdujemy tu również glosy komentujące wyroki różnych sądów w konkretnych sprawach. Jeszcze istotniejsze były moim zdaniem artykuły wpisujące się $\mathrm{w}$ powszechną w mediach hitlerowskich krytykę sędziów, sądów, prawa i wszystkich prawników. Zawierały one z reguły także postulaty przemian postaw sędziów w trakcie przygotowywania i formułowania orzeczeń. Inspiracją dla tych publikacji były w sposób ewidentny wypowiedzi samego Adolfa Hitlera. Powszechnie znany był jego pogardliwy stosunek wobec prawa, a przede wszystkim w odniesieniu do prawników. Jego osobiste ingerencje w poszczególne procesy oraz publiczna krytyka dotychczasowego wymiaru sprawiedliwości w Niemczech miały niewątpliwy wpływ na przemiany prawa (materialnego, procesowego oraz na organizacje struktur należących do wymiaru sprawiedliwości) ${ }^{1}$.

Kolejne podboje III Rzeszy spowodowały rozszerzenie merytoryczne „Deutsches Recht" o artykuły opisujące ustrój i prawa różnych jednostek terytorialnych podlegających okupacji niemieckiej. Jednym z takich organizmów było Generalne

1 F. Ryszka, Państwo stanu wyjątkowego. Rzecz o systemie państwa i prawa Trzeciej Rzeszy, Wrocław 1985, s. 472-506; A. Wrzyszcz, Okupacyjne sadownictwo niemieckie w Generalnym Gubernatorstwie 1939-1945. Organizacja i funkcjonowanie, Lublin 2008, s. 394-396. 
Gubernatorstwo. Był to twór o niejasnej pozycji ustrojowo-prawnej, który zmieniał swą nazwę. Początkowo brzmiała ona następująco: Generalne Gubernatorstwo dla okupowanych polskich obszarów. W dniu 31 lipca 1940 r. generalny gubernator Hans Frank wydał dekret odnoszący się do zmian organizacyjnych, powołując się na upoważnienie przekazane przez Hitlera. Na jego podstawie od 15 sierpnia oficjalną nazwą było Generalne Gubernatorstwo $(\mathrm{GG})^{2}$. Zmiana ta miała świadczyć o bliższym związku z Rzeszą Niemiecką. Nie ulega wątpliwości, że Generalne Gubernatorstwo zostało podporządkowane suwerenności Rzeszy, chociaż władze niemieckie nigdy nie doprecyzowały pozycji prawnoustrojowej $\mathrm{GG}^{3}$.

Ten brak konkretnych, precyzyjnych uregulowań widoczny był też na łamach „Deutsches Recht”. W tej sytuacji najbardziej celowe wydaje się omówienie opublikowanych tu pozycji w kolejności chronologicznej, gdyż pozwoli to na prześledzenie ewolucji poglądów prawników niemieckich w stosunku do Generalnego Gubernatorstwa, które niewątpliwie były uzależnione od sytuacji na frontach II wojny światowej, ale także od przetasowań w elitach władzy III Rzeszy. Trzeba wyraźnie podkreślić, że ze względu na ograniczone ramy objętościowe niniejszego artykułu niemożliwe jest przedstawienie pełnej analizy tekstów odnoszących się do ustroju i prawa GG wydrukowanych w omawianym czasopiśmie. Starałem się uwzględnić najważniejsze opracowania, dające możliwość refleksji nad polityką okupacyjną władz III Rzeszy w stosunku do Generalnego Gubernatorstwa.

Zgodnie z tym założeniem w pierwszej kolejności należy sięgnąć do prac Wernera Besta, niemieckiego prawnika, sędziego, członka NSDAP i wysokiego funkcjonariusza SS. Po wojnie został on osądzony i skazany za zbrodnie wojenne. Już w grudniu 1939 r. przygotował dla „Deutsches Recht” artykuł na temat nowego podziału i zarządu na terenach „byłego” państwa polskiego. Stanął jednoznacznie na stanowisku, iż Państwo Polskie utraciło swą niepodległość w drodze debellatio ${ }^{4}$. Kontynuacją rozważań w tej kwestii była jego publikacja książkowa z 1940 r. ${ }^{5}$

Natomiast za pierwszy znaczący artykuł w 1940 r. opublikowany na łamach omawianego czasopisma można uznać opracowanie Friedricha Wilhelma Adamiego poświęcone systemowi legislacyjnemu w Generalnym Gubernatorstwie

2 Warto podkreślić, że ten akt normatywny nie został ogłoszony drukiem w urzędowym publikatorze Generalnego Gubernatorstwa, jakim był Dziennik Rozporządzeń. Zamieszczono go natomiast w zbiorze przepisów opracowanych przez kierownika Wydziału Ustawodawstwa (od $1941 \mathrm{r}$. - Urzędu Ustawodawczego) w GG - Alberta Weha. Zob. A. Weh, Prawo Generalnego Gubernatorstwa w układzie rzeczowym z objaśnieniami i szczegółowym skorowidzem, Kraków 1941, A 102 Dekret w sprawie nowych uregulowań organizacyjnych w Generalnym Gubernatorstwie z 31 lipca 1940 r.; A. Wrzyszcz, Okupacyjne sadownictwo ..., s. 351-352.

3 A. Klafkowski, Okupacja niemiecka $w$ Polsce w świetle prawa narodów, Poznań 1946, s. $47-48,58-60,78-105$.

4 W. Best, Das Deutsche Kriegsrecht. Kriegs=Verwaltungsrecht. Die neue Gliederung und Verwaltung des ehemaligen polnischen Staatsgebietes, „Deutsches Recht“ 1939, s. 2089-2090.

5 Idem, Die Verwaltung in Polen. Zusammenbruch der Polnischen Republik, Berlin 1940. 
z perspektywy już kilkumiesięcznej praktyki. Podmiotami posiadającymi kompetencje do ustanawiania nowych przepisów prawnych były zarówno centralne władze III Rzeszy z Hitlerem na czele, jak i niemieckie organy okupacyjne utworzone dla Generalnego Gubernatorstwa (z generalnym gubernatorem oraz wyższym dowódcą SS i policji w pierwszej kolejności). Organizacja prac legislacyjnych, prowadzonych w ramach Urzędu Generalnego Gubernatora, należała najpierw do referenta generalnego, a od stycznia 1940 r. - do Wydziału Ustawodawstwa ( $A b$ teilung Gesetzgebung) ${ }^{6}$.

Kolejne istotne opracowanie zamieszczone w „Deutsches Recht” (zeszyt z 15 czerwca 1940 r.) zostało napisane przez zastępcę pełnomocnika gubernatora generalnego w Berlinie. Był to dr Julius von Medeazza. Zajął się on niemieckim przedstawicielstwem prawnym w Generalnym Gubernatorstwie ${ }^{7}$. Publikacja ukazała się na kilka miesięcy przed wydaniem rozporządzenia o niemieckich adwokatach w GG z 13 września 1940 r. ${ }^{8}$ Autor oparł się więc na lakonicznych przepisach rozporządzenia o sądownictwie niemieckim w Generalnym Gubernatorstwie z 19 lutego (weszło w życie 24 lutego) 1940 r. Zgodnie z nimi przewodniczący sądu miał prawo w konkretnym postępowaniu karnym dopuścić i powołać na obrońców wszystkie osoby, które posiadały uprawnienia do piastowania urzędu sędziowskiego w Rzeszy Niemieckiej, a nawet inne osoby posiadające niemiecką przynależność państwową lub narodową, dające gwarancję należytego wykonywania obrony. Warto podkreślić, że wykorzystał też znane mu informacje na temat położenia adwokatury Rzeczypospolitej Polskiej pod nadzorem niemieckich władz okupacyjnych w Generalnym Gubernatorstwie?

Ponad dwa miesiące później wydrukowano w omawianym czasopiśmie artykuł berlińskiego adwokata Jochena Thiesinga, który po uruchomieniu sądownictwa niemieckiego w GG został powołany na sędziego Wyższego Sądu Niemieckiego w Krakowie. Piastował także znaczące stanowiska w strukturach administracji niemieckiego resortu sprawiedliwości GG. Powierzono mu kierowanie referatami w oddziale I i II Głównego Wydziału Sprawiedliwości Rządu Generalnego Gubernatorstwa. Poza tym był zastępcą komisarza do spraw majątku wrogich państw ${ }^{10}$. Przedmiotem rozważań w tym artykule były zasady pomocy

$6 \quad$ F.W. Adami, Die Gesetzgebungsarbeit im Generalgouvernement. Ein Überblick über die bisher geleistete Aufbauarbeit, „Deutsches Recht“ 1940, s. 604-617; A. Wrzyszcz, Hierarchia aktów prawnych wprowadzonych przez okupanta niemieckiego w Generalnym Gubernatorstwie w latach 1939-1945, „Studia Iuridica Lublinensia” 2014, t. 22, s. 695-700.

7 J. von Medeazza, Die deutsche Rechtsvertretung im Generalgouvernement, „Deutsches Recht“"1940, s. 929-931.

8 A. Weh, Prawo Generalnego Gubernatorstwa ..., C 135 Rozporządzenie o niemieckich adwokatach w Generalnym Gubernatorstwie z 13 września 1940 r.

9 J. von Medeazza, Die deutsche Rechtsvertretung..., s. 930-931.

10 A. Wrzyszcz, Okupacyjne sadownictwo ..., s. 241, 286-287, 337. W opinii dr. Aleksandra Woltera, który w czasie okupacji był zatrudniony w Głównym Wydziale Sprawiedliwości Rządu 
prawnej z Generalnego Gubernatorstwa w sprawach cywilnych ${ }^{11}$. Autor skomentował akt normatywny wydany w GG w dniu 10 maja $1940 \mathrm{r}^{12}$ Skupił się przede wszystkim na praktycznych wskazówkach dla podmiotów niemieckich: w jaki sposób należy występować o pomoc prawną w sprawach cywilnych do GG i jak reagować na wnioski z GG. Podkreślił również wyłączność niemieckich organów resortu sprawiedliwości Generalnego Gubernatorstwa (zarówno sądów, jak i organów administracji resortu sprawiedliwości) w zakresie tych postępowań. Wyjaśnił, że sądy polskie pod nadzorem niemieckim w GG nie miały takich uprawnień oraz wskazał na przypadki naruszania tych przepisów przez sądownictwo polskie Generalnego Gubernatorstwa, szczególnie w kontaktach z sądami funkcjonującymi na terenach wcielonych do Rzeszy Niemieckiej ${ }^{13}$.

Pierwsza rocznica utworzenia Generalnego Gubernatorstwa zaowocowała okolicznościową publikacją zamieszczoną na łamach „Deutsches Recht” w dniu 26 października 1940 r. Autorem był ponownie von Medeazza. Wydaje się, że do jego obowiązków służbowych jako zastępcy pełnomocnika gubernatora generalnego w Berlinie należało informowanie szeroko rozumianej sfery prawniczej w III Rzeszy o statusie prawnym i ustrojowym $\mathrm{GG}^{14}$. Tekst ten jest w mojej ocenie peanem na cześć niemieckiego porządku prawnego i ustrojowego, wprowadzanego do organizacji administracji okupacyjnej na terenach Generalnego Gubernatorstwa.

Omawianie następnego rocznika „Deutsches Recht” z 1941 r. (Jahrgang 11) należy moim zdaniem rozpocząć od przywołania artykułu dr. hab. G. Hubernagela (nie udało mi się ustalić jego imienia, gdyż w urzędowych dokumentach niemieckich z tego okresu używano tylko inicjałów). Hubernagel pełnił bardzo ważne funkcje w strukturze resortu sprawiedliwości GG: sędziego Sądu Specjalnego w Radomiu, sędziego Wyższego Sądu Niemieckiego w Radomiu oraz prokuratora niemieckiego w Radomiu ${ }^{15}$. Przygotowane przez niego opracowanie zostało opublikowane w pierwszym zeszycie „Deutsches Recht” z 1941 r. Tytuł obejmował omówienie struktury i kompetencji sądów niemieckich w Gene-

Generalnego Gubernatorstwa jako rzeczoznawca i tłumacz, Thiesing zasłużył na pozytywną ocenę. Podlegały mu m.in. sprawy adwokatury w GG, starał się życzliwie traktować przedstawicieli polskiej palestry. Zob. Archiwum Instytutu Pamięci Narodowej w Warszawie (dalej: AIPN), Najwyższy Trybunał Narodowy (dalej: NTN), sygn. 313, k. 321, 333-334.

11 J. Thiesing, Rechtshilfeverkehr mit dem Generalgouvernement in Zivilsachen, „Deutsches Recht" 1940, s. 1400-1401.

12 A. Weh, Prawo Generalnego Gubernatorstwa ..., C 180 Zarządzenie o pomocy prawnej w sprawach cywilnych między władzami sprawiedliwości Generalnego Gubernatorstwa a sądami Rzeszy Niemieckiej z dnia 10 maja 1940 r.

13 J. Thiesing, Rechtshilfeverkehr mit dem Generalgouvernement ..., s. 1400-1401.

14 J. von Medeazza, Ein Jahr Generalgouvernement, „Deutsches Recht“ 1940, s. 1783-1801.

15 A. Wrzyszcz, Okupacyjne sadownictwo..., s. 424. 
ralnym Gubernatorstwie ${ }^{16}$. Trzeba przyznać, że autor zrealizował zapowiadane w temacie cele i dzięki niemu niemiecki czytelnik ,Deutsches Recht” mógł zapoznać się z syntetycznym opisem systemu sądownictwa niemieckiego i prokuratury niemieckiej w GG oraz z podziałem kompetencji między sądownictwo a prokuraturę, a także z zakresem właściwości poszczególnych organów należących do resortu sprawiedliwości Generalnego Gubernatorstwa. Poza tym uwzględnił system nadzoru administracyjnego (generalny gubernator i gubernatorzy dystryktów oraz podlegający im odpowiednio szefowie wydziałów sprawiedliwości). Poruszył też wiele innych kwestii ważnych dla porządku prawnego i ustrojowego w GG, m.in. zasady funkcjonowania rejestru handlowego, akt stanu cywilnego, reguły stosowania pomocy prawnej w sprawach cywilnych i karnych z różnymi podmiotami międzynarodowymi; ponadto odniósł się do instytucji doręczeń, czynności egzekucyjnych (w tym eksmisji), kosztów i opłat sądowych, wakacji sądowych, dopuszczalności oskarżeń prywatnych przed sądami niemieckimi, statusu ksiąg wieczystych, roli adwokatów niemieckich. W mojej ocenie Hubernagel starał się uwzględnić stan prawny obowiązujący w odniesieniu do sądownictwa niemieckiego w Generalnym Gubernatorstwie na koniec 1940 r. Jego publikacja miała dzięki temu zarówno wymiar propagandowy (zbliżająca się pierwsza rocznica utworzenia sądów niemieckich i wyższych sądów niemieckich w GG), jak i znaczenie praktyczne (bez wątpienia ułatwiała prawnikom z Rzeszy Niemieckiej prowadzenie spraw, w których pojawiały się aspekty ustrojowe i prawne związane z powołaniem i funkcjonowaniem Generalnego Gubernatorstwa) ${ }^{17}$.

Wspomniana wyżej pierwsza rocznica utworzenia powszechnego sądownictwa niemieckiego i równocześnie ponownego uruchomienia sądownictwa polskiego w GG (regulujące to akty normatywne zostały wydane 19 lutego 1940 r., a weszły w życie 24 lutego) była bezpośrednią przyczyną przygotowania kolejnego opracowania na interesujący nas temat w zeszycie 18 „Deutsches Recht” z 1941 r. Tytuł artykułu nawiązywał wprost do tego jubileuszu, a autorem był powoływany już wyżej Thiesing ${ }^{18}$. Analiza treści tej publikacji wskazuje, że uzasadnieniem były najprawdopodobniej przede wszystkim przesłanki propagandowe, gdyż według mnie są to informacje skierowane do opinii publicznej w III Rzeszy, a w szczególności do niemieckich prawników spoza Generalnego Gubernatorstwa. Wydaje mi się, iż te rozważania niewiele wnoszą pod względem merytorycznym, są mniej obszerne i tym samym były mniej przydatne w praktyce stosowania prawa w czasie II wojny światowej w GG w porównaniu z powoływanym wyżej artykułem Hubernagela.

16 G. Hubernagel, Aufbau und Aufgaben der deutschen Gerichte im Generalgouvernement, „Deutsches Recht“ 1941, s. 8-11.

17 Ibidem.

18 J. Thiesing, Ein Jahr deutsche Gerichte im Generalgouvernement, „Deutsches Recht“ 1941, s. 980-981. 
Kolejna wybrana przeze mnie publikacja to tekst Alberta Weha zamieszczony w zeszycie 36 „Deutsches Recht” z 6 września $1941 \mathrm{r}$. Autor był przez cały okres okupacji niemieckiej bliskim współpracownikiem generalnego gubernatora Hansa Franka. Jak wyżej wspomniano, stał na czele Wydziału Ustawodawstwa wchodzącego w skład Urzędu Generalnego Gubernatora do 1941 r., a następnie do 1945 r. - na czele Urzędu Ustawodawczego stanowiącego człon Sekretariatu Stanu, który obok wydziałów głównych tworzył strukturę Rządu Generalnego Gubernatorstwa ${ }^{19}$. W tym przypadku na pierwsze miejsce wysuwają się znów aspekty propagandowe. Bezpośredni powód powstania tej publikacji to nowe uregulowania dotyczące okupacji ziem zajętych przez Niemcy po ataku na Związek Sowiecki. Decyzje te miały bardzo istotne znaczenie dla GG, gdyż na ich podstawie powiększono jego obszar o tereny województwa stanisławowskiego, tarnopolskiego i części województwa lwowskiego. Z ziem tych utworzono piąty, największy dystrykt Generalnego Gubernatorstwa - dystrykt Galicja. Weh przywołał dekrety Hitlera z 17 i 22 lipca 1941 r. oraz w całości przytoczył proklamację generalnego gubernatora Franka z 1 sierpnia 1941 r. skierowaną do ludności Galicji ${ }^{20}$. Następnie przedstawił podstawy ustroju i prawa w nowym dystrykcie, powołując się na kilka rozporządzeń wydanych przez Franka także w dniu 1 sierpnia 1941 r. Zaakcentował szczególnie zasady organizacji niemieckiej administracji okupacyjnej, zajął się problemem języka urzędowego w tej nowej jednostce podziału terytorialnego (językiem urzędowym był język niemiecki, a języki polski i ukraiński były dopuszczone). Sporo uwagi poświęcił obowiązującemu tu prawu (podobnie jak na pozostałym obszarze GG przywrócono przepisy obowiązujące przed 1 września 1939 r., o ile nie były sprzeczne z przejęciem administracji przez Rzeszę Niemiecką). Artykuł kończy się pompatyczną konstatacją, że wskazane rozwiązania doprowadzą do tego, iż data 1 sierpnia 1941 r. będzie decydującym punktem zwrotnym w historii Galicji, początkiem epoki rozwoju gospodarczego i pokojowej pracy ${ }^{21}$.

W odróżnieniu od powyższego artykułu Weha następna wybrana przeze mnie publikacja miała charakter bardzo praktyczny. Jest to analiza orzecznictwa sądów Rzeszy Niemieckiej (niestety, nie udało mi się ustalić jej autora) dotycząca zakresu jurysdykcji sądów Rzeszy w sprawach rozwodowych, w których stronami nie byli obywatele III Rzeszy. Przyczyną tych rozważań był konkretny kazus, w którym pozwanym był obywatel Rzeczypospolitej Polskiej pochodzenia żydowskiego. Powódka zawarła z nim małżeństwo i utraciła w ten sposób obywatelstwo niemieckie. W realiach okupacyjnych na łamach „Deutsches Recht” okre-

19 A. Wrzyszcz, Okupacyjne sadownictwo..., s. 356-357.

20 A. Weh, Galizien, Bestandteil des Generalgouvernemants, „Deutsches Recht“ 1941, s. 1857; D. Schenk, Hans Frank. Biografia generalnego gubernatora, Kraków 2009, s. 193.

21 A. Weh, Galizien ..., s. 1858-1859. 
ślono pozwanego jako mieszkańca Generalnego Gubernatorstwa (zamieszkiwał w Warszawie). Powódka nie miała obywatelstwa niemieckiego, ale była osobą narodowości niemieckiej (Volksdeutsch). Wniosła pozew o rozwód do Sądu Krajowego (Landgericht) w Berlinie, ale sąd oddalił powództwo, gdyż uznał się za niewłaściwy dla rozpatrzenia tej sprawy. Autor opracowania zasugerował zmiany orzecznictwa sądów Rzeszy Niemieckiej w tym zakresie. Według niego dotychczasowa zasada oddalania powództw, gdy strona pozwana nie była obywatelem Niemiec, wynikała ze standardów prawa międzynarodowego, naruszałoby to bowiem suwerenność innych państw. Uznał, że Państwo Polskie zostało zlikwidowane, a więc argument ten nie ma już żadnego praktycznego znaczenia. Poza tym opowiedział się za przyjmowaniem powództw składanych nie tylko przez obywateli Rzeszy Niemieckiej, ale także przez osoby narodowości niemieckiej, gdyż oddalanie powództw utrudniałoby tym osobom starania o uzyskanie obywatelstwa III Rzeszy ${ }^{22}$.

Kolejna dość obszerna praca zamieszczona w „Deutsches Recht” w 1941 r. miała znów, niestety, charakter głównie propagandowy. Opublikowano na jego łamach przedmowę, którą wygłosił generalny gubernator Frank w trakcie uroczystości na Wawelu w dniu 26 października 1941 r. z okazji drugiej rocznicy utworzenia Generalnego Gubernatorstwa. W mojej ocenie był to tekst mający utwierdzać czytelników niemieckich „Deutsches Recht”, że działania niemieckich władz okupacyjnych zmierzały w dobrym kierunku. Brak tu jakichkolwiek merytorycznych odniesień do ustroju i prawa w GG. Znamienne jest jednak stwierdzenie, że Generalne Gubernatorstwo jest pierwszą wielką szkołą myślenia o zarządzaniu olbrzymimi obszarami świata, które będą podlegać III Rzeszy ${ }^{23}$.

W następnym roczniku ,Deutsches Recht” (1942) na wyróżnienie niewątpliwie zasługuje artykuł Lothara Wolfgramma odnoszący się do statusu niemieckiej adwokatury i notariatu w Generalnym Gubernatorstwie. Był to adwokat niemiecki, który pełnił ważne funkcje w strukturach administracji niemieckiego resortu sprawiedliwości GG. Od 1941 r. był zastępcą szefa oddziału II w Głównym Wydziale Sprawiedliwości Rządu Generalnego Gubernatorstwa - dr. Saage. Poza tym piastował stanowisko komisarza do spraw majątku wrogich państw do 1 lutego 1943 r., kiedy powołano go do Wehrmachtu. W 1940 r. zastępował dr. Saage jako pełnomocnika prasowego w Wydziale Sprawiedliwości Urzędu Generalnego Gubernatora $^{24}$. Artykuł Wolfgramma był informacją dla czytelników niemieckie-

22 „Deutsches Recht“" 1941, s. 2199-2200.

23 Der deutsche Aufbau im Generalgouvernement. Ansprache des Reichsleiters Generalgouverneur Dr. Frank am 26. Oktober 1941, „Deutsches Recht“ 1941, s. 2417-2418.

24 A. Wrzyszcz, Okupacyjne sadownictwo..., s. 284, 287, 289, 337. Według wspomnianego wyżej dr. Woltera Wolfgramm był zagorzałym hitlerowcem, ale nie był zaangażowany bezpośrednio w jakąś antypolską działalność, natomiast podejrzewano go o zachowania korupcyjne. AIPN, NTN, sygn. 313, k. 332-333. 
go czasopisma na temat niemieckiej adwokatury i notariatu w $\mathrm{GG}^{25}$. W porównaniu z przywołanym wyżej tekstem von Medeazzy z $1940 \mathrm{r}$. trzeba podkreślić, że w 1942 r. funkcjonowały już w praktyce ustrojowo-prawnej Generalnego Gubernatorstwa akty normatywne odnoszące się bezpośrednio do organizacji niemieckiej adwokatury (z 13 września 1940 r.) i notariatu (z 17 grudnia 1941 r.) ${ }^{26}$. Wolfgramm scharakteryzował zasady ubiegania się o wykonywanie zawodu niemieckiego adwokata i notariusza w GG oraz zdefiniował zakres ich kompetencji, podkreślając liczne ograniczenia (terytorialne, narodowościowe, wynikające $\mathrm{z}$ dualistycznego systemu sądownictwa - wrócę do tych kwestii w podsumowaniu). Stwierdził, że rozwiązania te miały charakter uproszczony i tymczasowy ze względu na toczącą się wojnę ${ }^{27}$.

Kolejna dość obszerna (w porównaniu z wykorzystywanymi dotychczas) publikacja z 1942 r. miała charakter wybitnie jurydyczny i obejmowała kilka komentarzy do wyroków wydanych przez sądy należące do systemu sądownictwa niemieckiego w Generalnym Gubernatorstwie (Wyższy Sąd Niemiecki w Krakowie, Wyższy Sąd Niemiecki w Radomiu, Sąd Niemiecki w Warszawie). W przywoływanym tekście uwzględniono cztery komentarze do wyroków z lat 19401942. Niestety, nie ustaliłem autorów analiz oceniających te orzeczenia ${ }^{28}$.

Przedmiotem rozważań dwóch fragmentów (na łamach „Deutsches Recht” oznaczono je numerami 11 i 12) były wyroki Wyższego Sądu Niemieckiego w Krakowie. Pierwszy z nich dotyczył zagadnienia przejmowania majątków prywatnych przez władze GG, drugi zaś odnosił się do konfiskaty towarów pochodzących z nielegalnego handlu. Przedstawione tu ustalenia znajdują się według mnie na dobrym poziomie technicznym w zakresie profesjonalizmu prawniczego. Uwzględniono bowiem najważniejsze akty normatywne ustanowione w GG (rozporządzenie o kształtowaniu cen w Generalnym Gubernatorstwie z 12 kwietnia 1940 r.; rozporządzenie o sądownictwie niemieckim w Generalnym Gubernatorstwie z 19 lutego 1940 r.; rozporządzenie o konfiskacie majątku prywatnego w Generalnym Gubernatorstwie; Ordynację Konfiskacyjną z 24 stycznia 1940 r. $)^{29}$ oraz przepisy obowiązujące w Rzeszy Niemieckiej (Verordnung über Strafen und Strafverfahren bei Zuwiderhandlungen gegen Preisvorschriften v. 3 Juni 1939) ${ }^{30}$.

25 L. Wolfgramm, Deutsche Rechtsanwälte und deutsche Notare im Generalgouvernement, „Deutsches Recht“" 1942, s. 1428-1429.

26 A. Weh, Prawo Generalnego Gubernatorstwa..., C 135; Rozporządzenie o niemieckich notariuszach w Generalnym Gubernatorstwie z 17 grudnia 1941 r., Dziennik Rozporządzeń dla Generalnego Gubernatorstwa, nr 120, s. 731-732.

27 L. Wolfgramm, op. cit., s. 1428-1429.

28 Deutsche Obergerichte im Generalgouvernement, „Deutsches Recht“ 1942, s. 1463-1465.

29 A. Weh, Prawo Generalnego Gubernatorstwa..., E 400, C 120, E 850.

30 Reichsgesetzblatt 1939, I, s. 999. 
Następny fragment, noszący numer 13, nawiązuje do wyroku Wyższego Sądu Niemieckiego w Radomiu. Był on wydany w trybie sprawdzania orzeczeń sądów polskich przez niemieckie organy resortu sprawiedliwości GG. Tak zwane prawo sprawdzenia przewidywało udział organów administracji resortu sprawiedliwości Generalnego Gubernatorstwa (wniosek kierownika wydziału sprawiedliwości w urzędzie gubernatora dystryktu) oraz wyższych sądów niemieckich ${ }^{31}$. Omawiany komentarz dotyczy podmiotowości prawnej gmin miejskich w GG. Jego autor rozważał różne punkty widzenia. Jeden z nich to konstatacja, że skoro państwo polskie przestało istnieć, to zlikwidowana została także osobowość prawna gmin miejskich funkcjonujących na jego terenie. Ostatecznie stanął jednak na odmiennym stanowisku i uznał, że gminy miejskie zachowały swą podmiotowość prawną, a wojna nie miała na to wpływu. Ponownie pragnę docenić sprawność techniczną jurydycznych wywodów uwzględniających analizę aktów normatywnych wprowadzonych przez okupanta niemieckiego dla ziem polskich. Pojawiają się jednak również aspekty historyczne i ideologiczne (utrzymanie podmiotowości prawnej gmin miejskich wywodzono ze średniowiecznych lokacji na prawie niemieckim) ${ }^{32}$.

Na szczególną uwagę zasługuje moim zdaniem pierwszy fragment przywoływanej publikacji (numer 10). Jest to komentarz do wyroku Sądu Niemieckiego w Warszawie opartego na przepisach wspomnianego wyżej rozporządzenia o konfiskacie majątku prywatnego w Generalnym Gubernatorstwie z 24 stycznia 1940 r. ${ }^{33}$ Przedmiotem rozważań jest status powierników ustanowionych w GG dla zarządzania cudzym majątkiem prywatnym zajętym przez niemieckie władze okupacyjne. Praktyka funkcjonowania powiernictwa miała szczególnie istotne znaczenie dla losów nieruchomości, których właścicielami byli członkowie społeczności żydowskiej ${ }^{34}$. Autor komentarza stwierdza, że w rozumieniu przywoływanego rozporządzenia powiernik nie był ustawowym reprezentantem właścicieli, ponieważ nie był on powołany wyłącznie do strzeżenia praw i interesów właścicieli. Z zakresu jego obowiązków służbowych wynikało przede wszystkim zapewnienie dbałości o interes publiczny zawierający się w zgodnym z przepisami zarządzaniu i utrzymaniu masy majątkowej. W omawianym tekście porównano status powiernika jako strony procesowej do pozycji syndyka masy upadłościowej, zarządcy przymusowego i wykonawcy testamentu ${ }^{35}$.

W podsumowaniu należy stwierdzić, że autorzy artykułów odnoszących się do ustroju i prawa Generalnego Gubernatorstwa publikowanych na łamach

31 A. Wrzyszcz, Okupacyjne sądownictwo..., s. 109-110.

32 Deutsche Obergerichte..., s. 1464-1465.

33 A. Weh, Prawo Generalnego Gubernatorstwa..., E 850.

34 M. Winstone, Generalne Gubernatorstwo. Mroczne serce Europy Hitlera, Poznań 2015, s. 111-112.

35 Deutsche Obergerichte..., s. 1463. 
„Deutsches Recht” w pełni identyfikowali się z ideologią narodowosocjalistyczną obowiązującą w III Rzeszy. W mojej ocenie znajduje to najbardziej dobitne odzwierciedlenie w kwestiach ustroju i administracji GG oraz w sprawach indywidualnych powodujących dyskryminację bądź ograniczenia ze względu na przynależność państwową, narodową (narodowościową), a zwłaszcza rasową (zgodnie z nazewnictwem używanym w Rzeszy Niemieckiej i na terenach okupowanych przez nią w czasie II wojny światowej). Na przykłady artykułowania takich poglądów wskazałem wyżej (jurysdykcja sądownictwa III Rzeszy w sprawach rozwodowych wobec osób, które nie posiadały obywatelstwa niemieckiego; ocena podmiotowości prawnej gmin miejskich w Generalnym Gubernatorstwie, którą wywodzono ze średniowiecznych lokacji na prawie niemieckim; status prawny i zadania powiernictwa niemieckiego w GG).

Wydaje się, że najbardziej reprezentatywną dziedziną, w której eksponowano na łamach „Deutsches Recht” ideologię nazistowską, są artykuły odnoszące się do adwokatury i notariatu w Generalnym Gubernatorstwie. Jednym z dobitnych przykładów jest powołane wyżej opracowanie von Medeazzy odnoszące się do przedstawicielstwa prawnego w GG, opublikowane w zeszycie z 15 czerwca $1940 \mathrm{r}$. Autor z entuzjazmem zaakceptował zarządzenie szefa dystryktu warszawskiego Ludwiga Fischera, na podstawie którego od 1 maja 1940 r. zabroniono wykonywania zawodu adwokatom Żydom, ale także polskim adwokatom uznanym przez kierownika Wydziału Sprawiedliwości w Urzędzie Szefa Dystryktu Warszawskiego za „podżegaczy"36.

Kontynuacją tej narracji jest przywołany wyżej artykuł Wolfgramma odnoszący się do niemieckiej adwokatury i notariatu w GG. Autor stwierdził, że niemieccy adwokaci (Rechtsanwälte) nie mogą przed sądami Generalnego Gubernatorstwa w żadnym przypadku reprezentować Żydów. Dopuszczono reprezentowanie Polaków, ale Wolfgramm podkreślił, iż niemieccy adwokaci mieli w takich sytuacjach pamiętać, że ich rola jest wyraźnie inna niż w Rzeszy. Według niego w realiach okupacyjnych niemiecki adwokat był organem wymiaru sprawiedliwości i przedstawicielem wszystkich Niemców na wysuniętym posterunku na Wschodzie. Zalecał maksymalną powściągliwość w kontaktach z polskimi klientami. Przed przyjęciem sprawy należało wnikliwie sprawdzić, czy charakter postępowania umożliwia podjęcie się pełnomocnictwa. Z drugiej strony popierał zaangażowanie niemieckich adwokatów w GG jako obrońców polskich oskarżonych, gdyż ich działalność jako „niemieckich strażników prawa i funkcjonariuszy wymiaru sprawiedliwości" powinna służyć dotarciu do prawdy ${ }^{37}$.

36 J. von Medeazza, Die deutsche Rechtsvertretung..., s. 931. Trzeba dodać, że czytelnicy „Deutsches Recht” mogli uzyskać wcześniej podstawowe informacje na ten temat z krótkiej notatki w rubryce Mitteilungen pod znamiennym tytułem: ,, Oczyszczenie” adwokatury warszawskiej (Mitteilungen. Säuberung der Warschauer Anwaltschaft, „Deutsches Recht“1940, s. 903).

37 L. Wolfgramm, op. cit., s. 1428-1429. 
Znamienne jest, że w następnych latach liczba publikacji odnoszących się do Generalnego Gubernatorstwa zamieszczonych na łamach „Deutsches Recht” oraz ich obszerność w drastycznym stopniu uległy ograniczeniu. Wydaje się, iż zaważyła na tym przede wszystkim sytuacja na frontach wojennych, a w związku z tym inne priorytety władz III Rzeszy, które znalazły odbicie także w tej sferze.

W mojej ocenie publikacje w niemieckim czasopiśmie „Deutsches Recht” w okresie II wojny światowej dotyczące ustroju i prawa Generalnego Gubernatorstwa były ewidentnie inspirowane i sterowane przez władze polityczne hitlerowskiego państwa. Autorzy najobszerniejszych, kompleksowych artykułów byli bezpośrednio zaangażowani w realizację okupacji centralnych ziem polskich (von Medeazza, Thiesing, Weh, Hubernagel, Frank, Wolfgramm). Nie ma więc żadnych wątpliwości, że trudno je w tym kontekście uznać za poważne opracowania o charakterze naukowym.

\section{BIBLIOGRAFIA}

\section{Archiwa}

Archiwum Instytutu Pamięci Narodowej w Warszawie, Najwyższy Trybunał Narodowy, sygn. 313.

\section{Literatura}

Adami F.W., Die Gesetzgebungsarbeit im Generalgouvernement. Ein Überblick über die bisher geleistete Aufbauarbeit, „Deutsches Recht“ 1940, s. 604-617.

Best W., Das Deutsche Kriegsrecht. Kriegs=Verwaltungsrecht. Die neue Gliederung und Verwaltung des ehemaligen polnischen Staatsgebietes, „Deutsches Recht“ 1939, s. 2089-2090.

Best W., Die Verwaltung in Polen. Zusammenbruch der Polnischen Republik, Berlin 1940.

Der deutsche Aufbau im Generalgouvernement. Ansprache des Reichsleiters Generalgouverneur Dr. Frank am 26. Oktober 1941, „Deutsches Recht“ 1941, s. 2417-2418.

Deutsche Obergerichte im Generalgouvernement, „Deutsches Recht“1942, s. 1463-1465.

Hubernagel G., Aufbau und Aufgaben der deutschen Gerichte im Generalgouvernement, „Deutsches Recht" 1941, s. 8-11.

Klafkowski A., Okupacja niemiecka w Polsce w świetle prawa narodów, Poznań 1946.

Medeazza J. von, Die deutsche Rechtsvertretung im Generalgouvernement, „Deutsches Recht“ 1940, s. 929-931.

Medeazza J. von, Ein Jahr Generalgouvernement, „Deutsches Recht“ 1940, s. 1783-1801.

Mitteilungen. Säuberung der Warschauer Anwaltschaft, „Deutsches Recht“ 1940, s. 903.

Rozporządzenie o niemieckich notariuszach w Generalnym Gubernatorstwie z 17 grudnia 1941 r., Dziennik Rozporządzeń dla Generalnego Gubernatorstwa, nr 120.

Ryszka F., Państwo stanu wyjątkowego. Rzecz o systemie państwa i prawa Trzeciej Rzeszy, Wrocław 1985.

Schenk D., Hans Frank. Biografia generalnego gubernatora, Kraków 2009.

Thiesing J., Ein Jahr deutsche Gerichte im Generalgouvernement, „Deutsches Recht“ 1941, s. $980-981$.

Thiesing J., Rechtshilfeverkehr mit dem Generalgouvernement in Zivilsachen, „Deutsches Recht“ 1940, s. 1400-1401.

Weh A., Galizien, Bestandteil des Generalgouvernemants, „Deutsches Recht“ 1941, s. 1857.

Weh A., Prawo Generalnego Gubernatorstwa w układzie rzeczowym z objaśnieniami i szczegółowym skorowidzem, Kraków 1941. 
Winstone M., Generalne Gubernatorstwo. Mroczne serce Europy Hitlera, Poznań 2015.

Wolfgramm L., Deutsche Rechtsanwälte und deutsche Notare im Generalgouvernement, „Deutsches Recht"1942, s. 1428-1429.

Wrzyszcz A., Hierarchia aktów prawnych wprowadzonych przez okupanta niemieckiego w Generalnym Gubernatorstwie w latach 1939-1945, „Studia Iuridica Lublinensia” 2014, t. 22.

Wrzyszcz A., Okupacyjne sadownictwo niemieckie w Generalnym Gubernatorstwie 1939-1945. Organizacja i funkcjonowanie, Lublin 2008.

\section{SUMMARY}

"Deutsches Recht" is a German magazine. It was important for lawyers in the Third Reich during World War II. In the pages of this periodical, apart from studies on the law in force in Germany, texts related to the system and law of the General Government were also published. The latter were mainly propaganda and, to a lesser extent, substantive. Among the authors of these publications prevailed people associated with the implementation of German occupation policy in GG (German functionaries of the occupation administration, German judges and lawyers).

Keywords: law; system; the General Government; the views of Nazi German lawyers

\section{STRESZCZENIE}

„Deutsches Recht” to niemieckie czasopismo, które w okresie II wojny światowej miało istotne znaczenie dla prawników w III Rzeszy. Na łamach tego periodyku, obok opracowań dotyczących prawa obowiązującego w Niemczech, publikowano także teksty odnoszące się do ustroju i prawa Generalnego Gubernatorstwa. Te ostatnie miały głównie charakter propagandowy, a w mniejszym stopniu - merytoryczny. Wśród autorów tych publikacji przeważały osoby związane z realizacją niemieckiej polityki okupacyjnej w GG (niemieccy funkcjonariusze administracji okupacyjnej, niemieccy sędziowie i adwokaci).

Słowa kluczowe: prawo; ustrój; Generalne Gubernatorstwo; poglądy nazistowskich prawników niemieckich 